\title{
SOME FOSSIL DIPTERA FROM FLORISSANT, COLORADO
}

\author{
By A. L. MELANDER \\ Riverside, California
}

Florissant, near Pike's Peak, Colorado, is a minor hamlet as towns go, but it is internationally renowned because of the multitude of Tertiary fossils that have been discovered near by. The small bluffs of laminated shale are being dug open piecemeal, to disclose layer upon layer of reminders of the living things of that region as they existed some twenty million years ago. The shale strata consist of solidified fine volcanic ash, blown out from adjacent volcanoes in Miocene times, with outbursts of poisonous gases to overwhelm the insects and other life of that time. Many of the fossils are perfectly preserved, but the majority of the soft-bodied Diptera are tantalizingly incomplete. Here or there a specimen is discovered with enough of its taxonomic parts in good condition, so that it can be classified as accurately as a pinned recent fly. It is my privilege to announce some remarkable finds in this article.

\section{Silvius merychippi (Cockerell) (Tabanidae)}

Allotype, male. I purchased at the Museum at the Florissant fossil beds a beautiful specimen of what is unquestionably the species described by Professor Cockerell as Tabanus merychippi. The neuration of both wings is perfect and shows the maculations and course of the veins as originally described for the female. The abdomen, however, is not marked with the obscure median stripe, but is evidently uniformly testaceous. The shape of the first and fourth posterior cells indicate the genus Silvius rather than Tabanus. The broad yellow body and large size suggests the modern Silvius gigantulus, though the wings are like those of $S$. pollinosus. There is no angulation nor spur on the branch of the third vein, the wing, even with the markings, being like Figure 16, page 152, of Curran's Manual of North American Diptera. 


\section{Leptogaster prior, n. sp. (Asilidae)}

(Plate II, Fig. 1)

Length $12 \mathrm{~mm}$., length of wing $7 \mathrm{~mm}$. Evidently a fuscous species, the comparatively stout abdomen indicating a female. Palpi not preserved; proboscis two-thirds the head-height. Lower part of pleura together with the mesonotum and metanotum darker than the upper pleura. Abdominal tergites darker than their sternites. Legs not annulate, but base of femora paler fuscous, outer part of hind femora and of hind tibia dark; hind tibiae enlarged distally, their pubescence plainly discernible in the specimen. Wings narrow and hyaline, the neuration well preserved, second vein arising before discal cell, fork of third vein arising beyond discal cell and continuing with only slight curve to wing-tip, the anterior side of the discal cell evidently angulate at the fork of the fourth and intercalary veins, fourth posterior cell petiolate.

A single specimen from the R. D. Lacoe collection, accession series number 38131, belonging to the United States National Museum. Leptogaster differs from other Asilidae by its slender form, limited chaetotaxy, reduced anal angle of the wing, long claws and vestigial pulvilli. The shape of the second posterior cell is also distinctive, extending over the discal cell and pointed at its proximal end. Leptogaster bears much the relation to the other Asilidae that the slender-bodied Systropinae do to the other Bombyliidae. The modern Systropus is elongate, nearly bare, long-legged, with anal angle and alulae of the wings reduced, and thus differs markedly from the stout furry beeflies. Although the extreme in Systropus has not been found in the Tertiaries, Professor Cockerell has made known several other of the nearly bare and slender Bombyliidae and has commented on their comparative abundance in early times.

Compared with some thirty recent species of Leptogaster in my collection, the Florissant specimen agrees exactly with flavipes Loew, in every detail of neuration, coloration and size. Flavipes is one of the commonest of the living Leptogasters and is widely distributed from Colorado to the Atlantic seaboard. Were the lives of the two not separated by the millions of years of time I would have placed the fossil with the living species. This is the species mentioned by Professor Cockerell in the Entomologist, 1913, page 214, and by Doctor James in the Journal 
of Palaentology, 1939, page 42, as occurring, but not described, in the Florissant beds. There is a species of Leptogaster described from the Tertiary formation of Kroatia, but prior is the first extinct species to be found in America.

\section{Asilus curculionis, n. sp. (Asilidae)}

(Plate II, Fig. 2)

Legs rather short, unicolorous, apparently red, tarsi gradually darker toward the tip, with uniform short rather coarse but not crowded dark brown pubescence; front femur with a row of eight long slender black bristles along its flexor edge; front metatarsus comparatively long, its sole with short stiff black bristles. This joint lacks the end, but enough is present to show that it is not of the abbreviated type of Echthistus. Middle tibiae with three macrochaetae present on the extensor surface; hind femora with about six bristles below, none visible on the upper side. The inner surface of the hind tibia shows a denser pubescence, as in some modern species. This surface is provided with two stout bristles, a character which among the recent species is almost invariably correlated with a long arista. Unfortunately the head, which would have offered valuable generic characters, is wanting. Wing eleven millimeters long, clear hyaline, showing no darkening at the tip or posterior border, veins firm and dark, fourth vein much arched at basal third of second posterior cell, fourth posterior cell proximally pointed and merely touching the tip of second basal cell, anterior crossvein placed a little beyond middle of discal cell. Body evidently darker than the legs, its macrochaetae black.

The right wing and the left hind leg are preserved to a remarkable degree. Remains of the thorax, the other wing, and parts of the legs are also visible on the stone, but are torn apart and more obscure. Modern robberflies readily macerate and their members easily dissociate if kept moist after death, and care must be taken if relaxing them lest they fall to pieces. From the neuration the insect is most certainly to be included in the broad genus Asilus. Comparison with recent material shows limited but almost exact agreement with several of the species. The neuration of Asilus in its broader sense is quite rigid. The smaller genera or subgenera into which Asilus has been segregated derive their characters scarcely at all from the wings. Color, character of the vestiture, and particularly the 
structure of the genitalia are the points used to separate the adjacent subdivisions.

The species evidently closely resembles Philonicus saxorum James, but the wing-veins are much darker, the second submarginal cell distally is less bell-shaped, the first posterior cell is less constricted at the middle, and the fourth posterior cell is not pedunculate at its base. I have compared the fossil with over fifty species of the Asilus complex before me, which are distributed among fourteen of its twenty subgenera. From some of the groups, e.g., Asilus s.str., Pampomerus, Tolmerus, etc., the fossil can be at once isolated because of the nature of its vestiture and its neuration. Of the species before me it compares most favorably with Heligmoneura. The apparently red legs, the nature of their pubescence and bristles, and the hyaline wings are quite like the European $H$. flavipes Meigen. But the fossil shows a difference in having black bristles, longer front metatarsi and more arched second posterior cell. The Florissant specimen is probably a female for the bristles of the front femora are stronger than in the male of Heligmoneura, and there is none of the shaggy hairs underneath the front femora.

In size the fossil resembles our common Tolmerus notatus, but its bristles are much less evident and its legs are shorter. Although it does not belong to this division of Asilus it will be convenient to compare with notatus, inasmuch as Professors Cockerell and James have compared other fossil Asilidæ with this wide-spread recent form. The tip of the marginal cell is as in notatus, and therefore blunter than in peritulus or amelanchieris; the second submarginal cell is considerably shorter than in either notatus or Cockerell's species; the second posterior cell bulges as in peritulus; the anterior crossvein is as in notatus, but slightly beyond middle of the discal cell; the fourth posterior cell is as in notatus and amelanchieris.

The type bears the accession series number 38131, and is from the R. D. Lacoe collection of the National Museum. This beautiful fossil shows intermingled with the parts of the fly the remains of a beetle in part well preserved. From the robust body, strong clavate femora, broadened tarsi and the pitting and squamæ of the legs and body it appears that the beetle is a weevil, similar to Phymatodes. It is not unlikely that the Asilus was overwhelmed just after securing the weevil as its prey. 


\section{Apolysis magister, n. sp. (Bombyliidae)}

(Plate II, Fig. 3)

Length $9 \mathrm{~mm}$. A rather stout, apparently bare species whose generic position is indicated by the peculiar antennæ and open discal cell. Proboscis porrect, twice the depth of the head, palpi not preserved nor is the labella. Antennæ short, the first two joints globular, the first a little larger than the second and neither showing any hairs; third joint quadrate and blunt, widening below just before the middle, in length equal to the basal joints combined, bearing a minute style inserted just above the middle of its apex but not in a depression of the joint. Thorax large and domed. Abdomen large, conical, showing eight segments but the tip of the abdomen is not preserved, the individual segments posteriorly with narrow light-colored incisures. From the fulness of the abdomen it would seem that the fossil represents a gravid female. Legs slender, showing no bristles. Wings uniformly hyaline except that the marginal cell is darker; veins of the anterior portion well preserved, those of the hind part of the wing very faint and in part impossible to decipher. Two submarginal cells present, the second acute and long, the third vein forking opposite end of first vein with the branch terminating at wing-tip, third vein straight, anterior crossvein before middle of wing, discal cell open, confluent with the second posterior cell, three posterior cells present, the shape of the anal cell not recognizable. The species does not show a sign of the delicate scattered pubescence characteristic of the modern. species.

Holotype and counter type: collected in 1906 by Cockerell, Wheeler and Rohwer, at Station 14 (See Bull. Am. Mus. Nat. Hist., XXIII, Art. IV.) and deposited in the American Museum of Natural History. Both halves of the stone show the fossil. Paratype: from the R. D. Lacoe collection in the National Museum, accession lot number 38575 .

I have carefully looked for the posterior crossvein normally at the end of the discal cell, using the binocular microscope with every sort of lighting, without success; nor is there any angulation evident in the fourth and fifth longitudinal veins to indicate a crossvein. The species is therefore to be located in the genus Apolysis, which was erected by Loew for a South African species which is pictured in the Dipterenfauna Süd- 
afrikas. There are now six more species recorded from South Africa and two palaearctic species from Europe and Siberia. Although up to the time of writing, the genus Apolysis has not been recognized as found in America, I have in press for publication in the Annals of the Entomological Society of America a tabulation of nine species, eight of which are new, which occur in Southern and Lower California. ${ }^{1}$ The recent American species are small, ranging from 0.75 to $3 \mathrm{~mm}$., hence the name selected for the large Tertiary species, magister, Latin, the leader of his tribe.

${ }^{1}$ Since published in vol. 39 , no. 3, pp. 451-495.

\section{Description of Prate II}

Fig. 1, Leptogaster prior, n.sp. $\left(\times^{6}\right) ; 2$, Asilus curculionis, n.sp. $(\times 4.4)$; 3, Apolysis magister, n.sp. ( $\times 6)$

\section{The Genotype of Mimetus Hentz}

Some time ago, Mr. Banks called my attention to a curious mistake in the selection of the genotype of the genus Mimetus Hentz, a well known genus of spiders.

The genus of Mimetus was erected by Hentz in 1832, in an article "On North American Spiders" in Silliman's Journ. Sci. Arts, 21, pp. 99-152. The article is reprinted in the collected papers of Hentz in 1875, in the Occ. Pap. Boston Soc. Nat. Hist., vol. 2, pp. 1-15. This is the edition usually used. In the 1832 article, Hentz mentions but one species, Mimetus syllepsicus and of this he had only one specimen which he found in the web of Eperia labyrinthea.

In the paper of 1850, Journ. Boston Soc. Nat. Hist., pp. 18-35, Hentz redefines the genus and describes three species, $M$. interfector, M. tuberosus and $M$. syllepsicus. The first species, $M$. interfector, has been recognized as the genotype and the other two have been considered as synonyms. But by the generally accepted rules of taxonomy, the single species used at the time the genus was defined, automatically becomes the genotype, so if this rule is followed the genotype of Mimetus is syllepsicus Hentz.

- E. B. BRYANT 

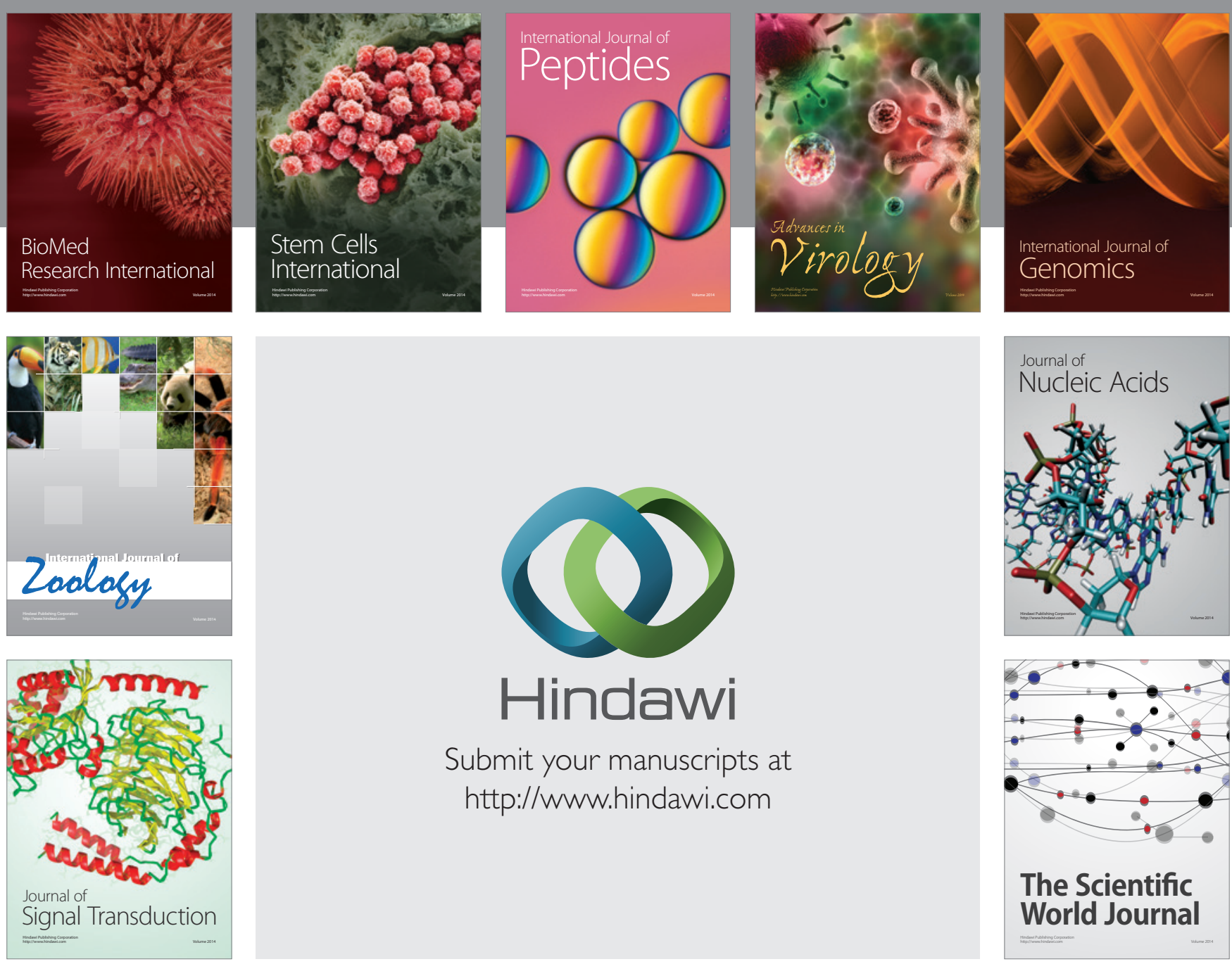

Submit your manuscripts at

http://www.hindawi.com
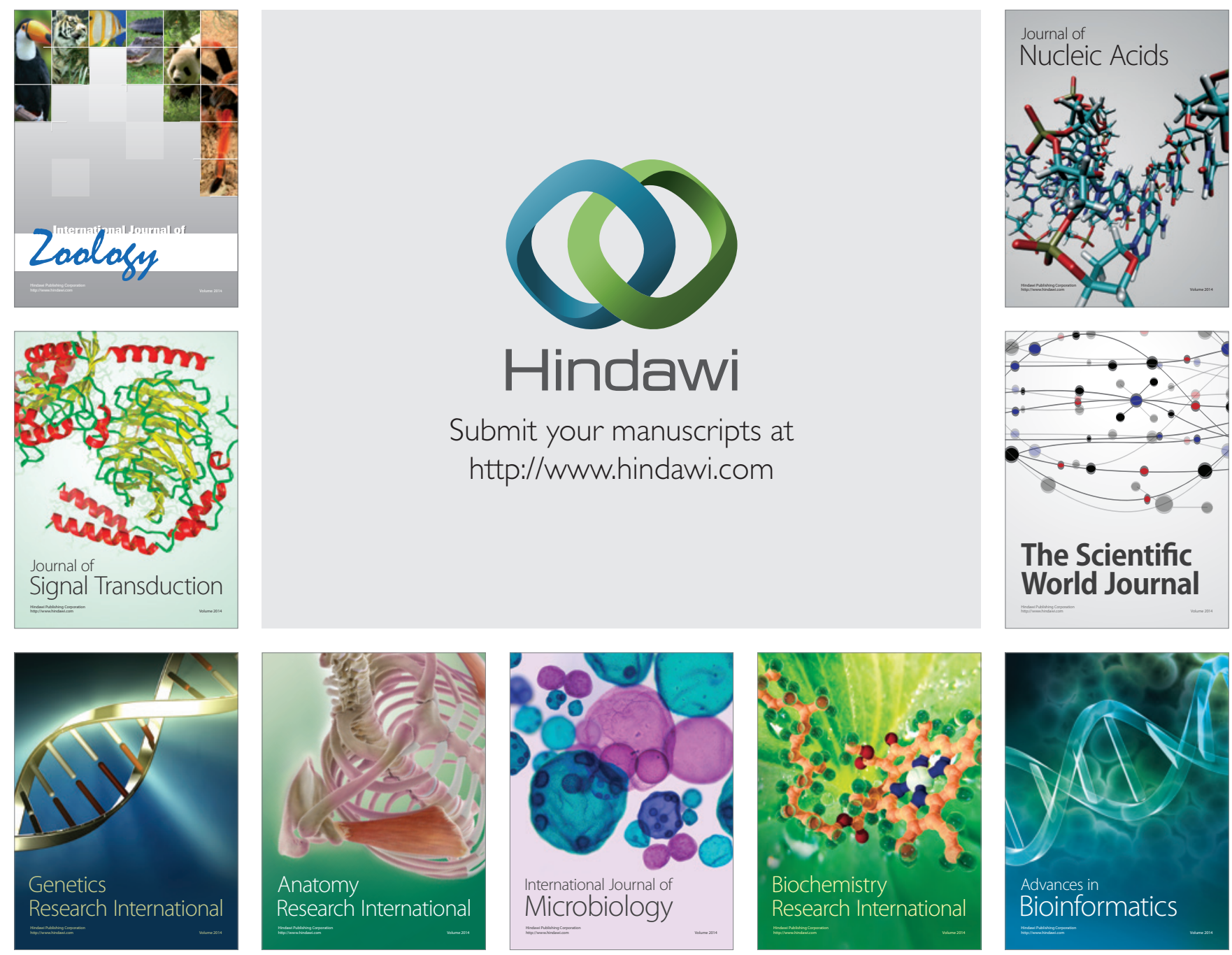

The Scientific World Journal
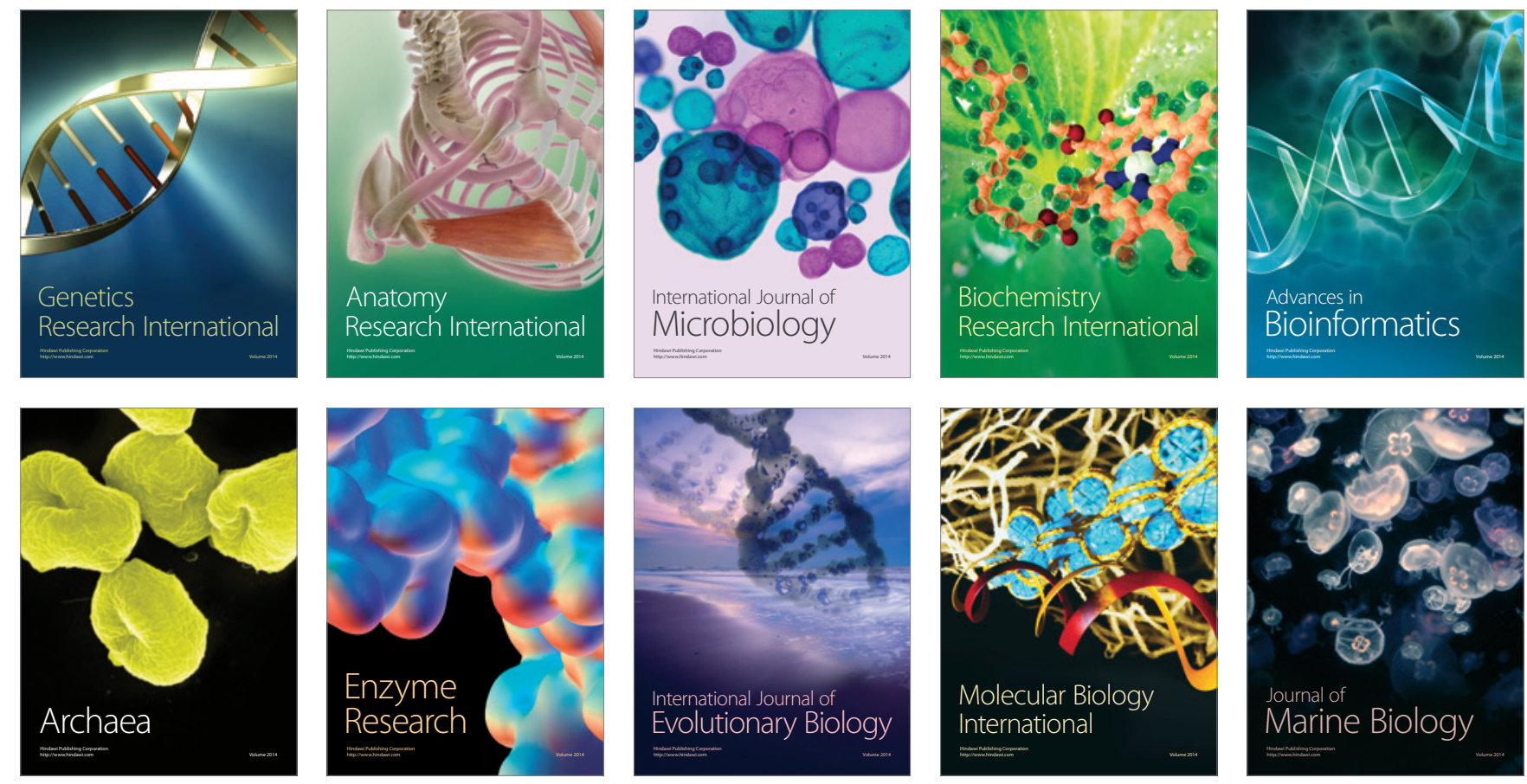